\title{
Analisis Strategi Pemasaran Online Untuk Meningkatkan Volume Jumlah Mahasiswa di masa Pandemi Covid-19 (Studi Kasus Pada Tim Promosi Online Fisip Universitas Sangga Buana)
}

\author{
Yuyun Yuniarsih ${ }^{\mathrm{a}}$, Muhammad Dadi Priadi ${ }^{\mathrm{b}}$, Ridwan Tho At Firdaus ${ }^{\mathrm{c}}$, Silsi Sabila $^{\mathrm{d}}$ \\ a,b,c,d Universitas Sangga Buana YPKP Bandung \\ yuyun.yuniarsih@usbypkp.ac.id
}

\begin{abstract}
Abstrak
Di bidang layanan pendidikan, globalisasi telah membantu pembentukan persaingan sengit. Banyaknya jumlah institusi menciptakan persaingan untuk calon siswa; universitas bersaing satu sama lain untuk menarik siswa, sementara siswa menjadi lebih kritis dalam keputusan pemilihan perguruan tinggi mereka. Lembaga akhirnya menyusun strategi pemasaran untuk menarik mahasiswa; namun demikian, rekrutmen mahasiswa bukan semata-mata tugas Panitia Penerimaan Mahasiswa Baru atau Biro Promosi; seluruh warga kampus bertanggung jawab untuk memajukan kampus. Selama dua tahun terakhir, FISIP Universitas Sangga Buana memiliki tim Promosi Online. Metode kualitatif diterapkan dalam penelitian ini. Penelitian ini bertujuan untuk melihat apakah Tim Promosi Fisip Online Universitas Sangga Buana dapat membuat strategi pemasaran online untuk mendongkrak jumlah mahasiswa baru yang akan mendaftar di masa pandemi Covid-19. Dampak dari strategi bersaing, strategi pemasaran, kualifikasi SDM, atau bergesernya aspirasi calon mahasiswa terhadap kesenjangan antara jumlah pelamar atau calon pelamar dengan jumlah yang diharapkan diterima di Perguruan Tinggi Swasta (PTS) merupakan dampak dari strategi bersaing, pemasaran strategi, kualifikasi SDM, atau pergeseran aspirasi calon mahasiswa. Di akun Instagram kampus, temuan riset tentang taktik pemasaran online untuk meningkatkan jumlah mahasiswa selama pandemi berjalan dengan baik. Kendalanya adalah tidak semua akademisi ingin mempromosikan konten promosi online, yang membuat pemasaran internet menjadi kurang efektif. Dari penelitian ini diharapkan seluruh dosen dan mahasiswa Universitas Sangga Buana dapat menyumbangkan ide dan sarannya kepada tim promosi guna meningkatkan strategi pemasaran online dan mempromosikan universitas di berbagai platform media sosial menggunakan konten yang dibuat oleh tim promosi online.
\end{abstract}

Kata Kunci : Strategi, Pemasaran Online, Kampus, Dimasa Pandemi

\begin{abstract}
Globalization has encouraged the emergence of very competitive competition in the world of educational services. The large number of universities causes competition to get prospective students, universities compete with each other to attract prospective students and students are increasingly critical in making decisions to choose a college. The university finally developed a marketing strategy to attract students, student recruitment is not only the responsibility of the New Student Admissions Committee or the Promotion Bureau, promoting the campus is the duty of all campus residents. FISIP Sangga Buana University formed an Online Promotion team which has been running for 2 years. The method used is a qualitative method. The purpose of this study was to determine the planning of online marketing strategies to increase the volume of the number of new students who will enter during the Covid-19 pandemic by the Fisip Online Promotion Team of Sangga Buana University. The gap between the number of applicants or prospective applicants and the number expected to be accepted in private universities (PTS), is the impact of competitive strategies, marketing strategies used, qualifications of Human Resources (HR) or shifting aspirations of prospective students. The results of the online marketing strategy research to increase the volume of the number of students during the pandemic went well on the campus Instagram account. The inhibiting factor is not all lecturers want to promote online promotional content, then online marketing is still less effective. From this research, it is hoped that all lecturers and students at Sangga Buana University to contribute ideas and ideas to the promotion team so that online marketing strategies are better and also want to promote campus to various social media with content that has been created by the online promotion team.
\end{abstract}

Keyword: Strategy, Online Marketing, Campus, During The Pandemic 


\section{PENDAHULUAN}

Globalisasi telah mendorong timbulnya persaingan yang sangat kompetitif dalam dunia jasa pendidikan. Jumlah perguruan tinggi yang banyak, menyebabkan terjadinya persaingan yang ketat dalam mendapatkan calon mahasiswa, Perguruan tinggi saling berlomba untuk mengembangkan seluruh potensi dan kemampuannya guna menarik minat calon mahasiswa. Di samping semakin ketatnya persaingan, masalah lain yang dihadapi perguruan tinggi adalah semakin kritisnya mahasiswa dalam mengambil keputusan untuk memilih sebuah perguruan tinggi.

Calon mahasiswa dapat memilih banyak alternatif pendidikan sehingga mereka memperhatikan model pendidikan dan prospek kerja setelah lulus kuliah. Oleh karena permasalahan tersebut, pihak perguruan tinggi perlu menyusun strategi pemasaran untuk memenangkan persaingan, semua jajaran yang berada di perguruan tinggi harus bersama melakukan action untuk menarik peminatan mahasiswa untuk memilih perguruan kita, tetapi banyak pemikiran yang dianggap keliru apabila perekrutan mahasiswa itu menjadi tanggung jawab Panitia Penerimaan Mahasiswa Baru (PMB) atau Biro Promosi saja, ini adalah anggapan yang keliru, mempromosikan kampus adalah tugas semua warga kampus, di Universitas Sangga Buana khususnya di Fakultas Ilmu Sosial dan Politik (FISIP) membentuk suatu team Promosi Online Fisip yang sudah berjalan dua tahun ini.

Strategi Pemasaran menurut (Kotler dan Amstrong, 2008) adalah logika pemasaran dimana perusahaan berharap dapat menciptakan nilai bagi customer dan dapat mencapai hubungan yang menguntungkan dengan pelanggan. Pemasaran online menurut (Kotler, 2008), dijelaskan bahwa pemasaran online merupakan proses sosial dan manajerial bagi individu maupun kelompok. Proses tersebut mengatur individu dan kelompok tadi dalam memperoleh kebutuhan dan keinginan mereka dengan membuat, menawarkan dan melakukan jual beli. Pada prinsipnya pemasaran online hampir sama dengan pemasaran pada umumnya, hanya berbeda pada media pemasarannya.

Mentransformasikan strategi pemasaran menjadi program pemasaran, manajer pemasaran harus membuat keputusan mendasar dalam hal pengeluaran pemasaran, alat bauran pemasaran (marketing mix) dan alokasi pemasaran. McCarthy mempopulerkan sebuah klasifikasi empat unsur dari alat bauran pemasaran (marketing mix) yang dikenal dengan empat P (four Ps),yaitu: produk, harga, tempat dan promosi (product, price, place, promotion) (Kotler, 2008).

Pemasaran online merupakan proses sosial dan manajerial bagi individu maupun kelompok. Proses tersebut mengatur individu dan kelompok tadi dalam memperoleh kebutuhan dan keinginan mereka dengan membuat, menawarkan dan melakukan jual beli.

WHO (World Health Organization atau Badan Kesehatan Dunia) secara resmi mendeklarasikan Virus Corona sebagai pandemi pada tanggal 9 Maret 2020. Artinya, Virus Corona telah menyebar secara luas di dunia. Istilah pandemi terkesan menakutkan tapi sebenarnya itu tidak ada kaitannya dengan keganasan penyakit tapi lebih pada penyebarannya yang meluas. Ingat, pada umumnya Virus Corona menyebabkan gejala yang ringan atau sedang, seperti demam dan batuk, dan kebanyakan bisa sembuh dalam beberapa minggu. Tapi bagi sebagian orang yang berisiko tinggi (kelompok lanjut usia dan orang dengan masalah kesehatan menahun, seperti penyakit jantung, tekanan darah tinggi atau diabetes), Virus Corona dapat menyebabkan masalah kesehatan yang serius. Kebanyakan korban berasal dari kelompok berisiko itu. Karena itulah penting bagi kita semua untuk memahami cara mengurangi risiko, mengikuti perkembangan informasi dan tahu apa yang dilakukan bila mengalami gejala. Dengan demikian kita bisa melindungi diri sendiri dan orang lain.

Tim Promosi Online Fisip Universitas Sangga Buana pada awalnya dibentuk sebelum masa pandemi dalam rangka mempromosikan kampus khususnya prodi Ilmu Komunikasi dan Administrasi Bisnis. Dengan melibatkan seluruh unsur Fakultas dari mulai dekan fakultas juga para dosen tetap baik Ilkom maupun Adbis, melibatkan juga beberapa mahasiswa baik dari prodi Ilkom, Adbis dan Crew TV yang kegiatannya langsung terjun ke sekolah-sekolah untuk membantu mempromosikan kampus secara langsung ke sekolah-sekolah yaitu SMA, SMK, MA, baik negeri maupun swasta dengan cara membuat MOU atau MOK dengan sekolah-sekolah tersebut. Kegiatan ini sudah berlangsung sebelum masa pandemi bertatap muka langsung dengan siswa-siswi sekolah baik didalam kelas maupun di aula, perkenalan kampus dilaksanakan langsung kepada siswa siswi untuk menjaring peminatan masuk ke Universitas Sangga Buana YPKP Bandung karena masa pandemi berlangsung hampir satu tahun sehingga kegiatan tersebut tidak bisa dilaksanakan secara luring oleh karena itu atas prakarsa wakil dekan dibuat Tim Promosi Online Fisip atau Tim Inti yang kegiatannya membantu mempromosikan biro promosi kampus secara

\section{METODE PENELITIAN}

Penelitian ini menggunakan metode Studi Kasus, sebab kondisi aktual dari keadaan atau situasi, studi kasus, berasal dari terjemahan dalam bahasa Inggris "A Case Study" atau "Case Studies". Kata "Kasus" diambil dari kata "Case" yang menurut Kamus Oxford Advanced Learner's Dictionary of Current English (1989), diartikan sebagai: 1). Contoh kejadian sesuatu, 2). Kondisi aktual dari keadaan atau situasi, dan 3). Lingkungan atau kondisi tertentu tentang orang atau sesuatu. Dari penjabaran definisi tersebut dapat ditarik kesimpulan bahwa Studi Kasus ialah suatu serangkaian kegiatan ilmiah yang dilakukan secara intensif, terinci dan mendalam tentang suatu program, peristiwa dan aktivitas, baik pada tingkat perorangan, sekelompok orang, lembaga atau organisasi untuk memperoleh pengetahuan mendalam tentang peristiwa tersebut. Oleh karena itu peneliti menggunakan metode studi kasus untuk meneliti tentang pemasaran kampus secara Online pada masa Pandemi Covid19. 
Menurut Endraswara (2012), dalam metode Studi Kasus, hendak memahami fenomena secara mendalam, bahkan mengeksplorasi dan mengelaborasinya, menurut Yin (1994: tidak cukup jika pertanyaan Studi Kasus hanya menanyakan "apa"(what), tetapi juga "bagaimana"(how) dan "mengapa"(why). Pertanyaan "apa" dimaksudkan untuk memperoleh pengetahuan deskriptif (descriptive knowledge), "bagaimana"(how) untuk memperoleh pengetahuan eksplanatif (explanative knowledge) dan "mengapa"(why) untuk memperoleh pengetahuan eksploratif (explorative knowledge). Yin menekankan penggunaan pertanyaan "bagaimana" dan "mengapa", karena kedua pertanyaan tersebut dipandang sangat tepat untuk memperoleh pengetahuan yang mendalam tentang gejala yang dikaji. Selain itu, bentuk pertanyaan akan menentukan strategi yang digunakan untuk memperoleh data. Langkah yang akan dilaksanakan dalam penelitian menggunakan metode studi kasus pada penelitian ini :

\section{Pemilihan Tema,}

\section{Pembacaan Literatur}

Kumpulkan sebanyak mungkin literatur atau bahan bacaan, seperti jurnal, publikasi ilmiah, temuan studi masa lalu, buku, majalah, dan surat kabar yang relevan dengan kasus. Membaca literatur, menurut Yin (1994), sangat penting bagi para peneliti dalam subjek untuk memperluas perspektif mereka dan mempertajam rumusan masalah yang akan diajukan.

3. Perumusan Fokus dan Masalah Penelitian 4.Data penelitian Studi Kasus

Dapat diperoleh dari beberapa teknik, seperti wawancara, observasi pelibatan (participant observation) dan dokumentasi

\section{Penyempurnaan Data}

Dilakukan dengan membaca keseluruhan data dengan merujuk ke rumusan masalah yang diajukan. Jika rumusan masalah diyakini dapat dijawab dengan data yang tersedia, maka data dianggap sempurna.

\section{Pengolahan Data}

Setelah data dianggap sempurna, peneliti melakukan pengolahan data, yakni melakukan pengecekan kebenaran data, menyusun data, melaksanakan penyandian (coding), mengklasifikasi data, mengoreksi jawaban wawancara yang kurang jelas. Tahap ini dilakukan untuk memudahkan tahap analisis.
7. Analisis Data. Setelah data berupa transkrip hasil wawancara dan observasi, maupun gambar, foto, catatan harian subjek dan sebagainya dianggap lengkap dan sempurna, peneliti melakukan analisis data.

Gambar 2.1

Langkah-langkah yang dilakukan dalam dalam penelitian menggunakan metode studi kasus pada penelitian ini .

Sumber : peneliti

\section{HASIL DAN PEMBAHASAN Hasil Penelitian}

1. Perencanaan strategi pemasaran online untuk meningkatkan volume jumlah mahasiswa di masa pandemi ini.

Promosi Online telah berjalan dua tahun, karena adanya Pandemi sehingga berkendala untuk melakukan Promosi Offline. Sebelum itu, promosi dilakukan secara langsung, yaitu terjun ke lapangan seperti disebarkan ke siswa/i SMA, SMK dan MA. Promosi Online ini berbentuk Tim, yaitu Tim Promosi Online Fisip yang diketuai oleh Pak Daniel. Seluruh informasi ada dalam Tim Promosi Online.

Selain Fisip, atau umumnya, promosi online dilakukan pada akun Instagram kampus dan lebih lengkapnya pada akun Instagram Fisip.

Selanjutnya kegiatan yang dilaksanakan promosi online yaitu melakukan perencanaan dan menentukan tema konten yang akan di buat untuk pemasaran online. Lalu mempublish semua mahasiswa berprestasi dan dosen yang ahli di bidangnya.

Fakultas berperan membantu tim promosi online dalam menyediakan konten. Tim promosi online membuat timeline lalu mendesign konten tersebut kemudian fakultas membantu menyediakan caption yang menarik. Setelah itu tim promosi online menentukan platform sosial media yang paling sering digunakan yaitu di Instagram dan Facebook dengan memasang iklan tersebut di Instagram dan Facebook.

2. Faktor yang menjadi pendukung dan penghambat strategi pemasaran online untuk meningkatkan volume jumlah mahasiswa di masa pandemi ini.

Faktor Pendukung Promosi Online, diantaranya

- SDM

- Anggaran (khusus)

- Tim kompak

- Pemasaran secara online yaitu karena semua orang memakai gadget. Pemasaran melalui platform social media sangat mendukung.

- Memiliki SDM yang kreatif dan mampu menggunakan software untuk mendesign kontenkonten video, audio dan foto semenarik mungkin.

Faktor Penghambat :

- Belum semua dosen mau mempromosikan konten yang telah dibuat oleh Fisip. 
- Terkadang pemasaran secara online kurang efektif karena masih di butuhkannya pemasaran secara langsung atau offline agar pesan yang disampaikan tersampaikan dengan baik.

3. Jenis-jenis promosi pemasaran yang diterapkan oleh Fakultas Fisip Universitas Sangga Buana dalam menarik minat mahasiswa di masa pandemi.

Untuk fisip sendiri, sering mengadakan webinar pelatihan dengan adanya hadiah menarik seperti beasiswa USB, tabungan emas, tab, dll. Sudah sampai pada dua wilayah, yaitu di Bandung Barat berpusat di Lembang dan Bandung Timur berpusat di Tasikmalaya. Membuat konten secara online di Instagram dan media social lain, lalu memasang iklan di berbagai platform media social, yaitu :

a) Menggunakan media social sesuai dengan target closing marketing.

b) Melalui event-event bersama lembaga-lembaga external dengan menyelipkan konten-konten dan promosi.

4. Cara Fakultas Fisip membangun brand awareness di internet untuk menggaet perhatian calon mahasiswa.

- Memperbanyak event-event external.

- Membangun kerjasama dengan lembaga media-media eksternal agar lebih dikenal oleh banyak orang.

- Meningkatkan dan menjaga kualitas mahasiswa dan dosen.

- Mempertahankan serta meningkatkan akreditasi.

- Membuat post seperti sapaan "Ilkomers" dan " Keren Adbis" .

- Dengan melihat persaingan Universitas di Bandung yang sangat ketat. Dari ilkom sangat di unggulkan lab ilmu komunikasi yang sudah berjalan cukup lama.

5. Cara pelayanan Fakultas Fisip terhadap calon mahasiswa baru yang telah mendaftar secara online.

- Pendaftaran selama masa pandemic secara online dan offline.

- Fakultas membantu untuk promosi.

- Setelah calon mahasiswa masuk ke Fakultas Fisip akan diberikan pelayanan secara penuh dan dilakukan pembinaan oleh dosen wali.

- Menyambut Mahasiswa Baru dengan membuat suatu acara yang menarik dengan tema yang mengikuti perkembangan anak milenial.

- Menciptakan citra para dosen yang tidak kaku dan menyenangkan lewat acara penyambutan tersebut.

- Menggunakan link yang akhirnya akan berpusat dan mengumpulkan para calon mahasiswa.

\section{Pembahasan}

1. Perencanaan strategi pemasaran online untuk meningkatkan volume jumlah mahasiswa di masa pandemic ini. Strategi Pemasaran menurut (Kotler dan Amstrong, 2008) adalah logika pemasaran dimana perusahaan berharap dapat menciptakan nilai bagi customer dan dapat mencapai hubungan yang menguntungkan dengan pelanggan. Pemasaran online menurut Kotler (2008).
Bila dikaitkan teori tersebut dengan hasil penelitian, maka promosi online dapat berjalan, karena adanya strategi yang dilakukan walaupun pada masa Pandemi sehingga tidak berkendala untuk melakukan promosi walaupun tidak offline. Karena sebelum masa pandemi promosi dilakukan secara langsung, yaitu terjun ke lapangan seperti disebarkan brosur ke siswa/i yang berada di sekolah. Promosi Online ini berbentuk Tim. Seluruh informasi ada dalam Tim Promosi Online dan Tim membuat konten-konten promosi.
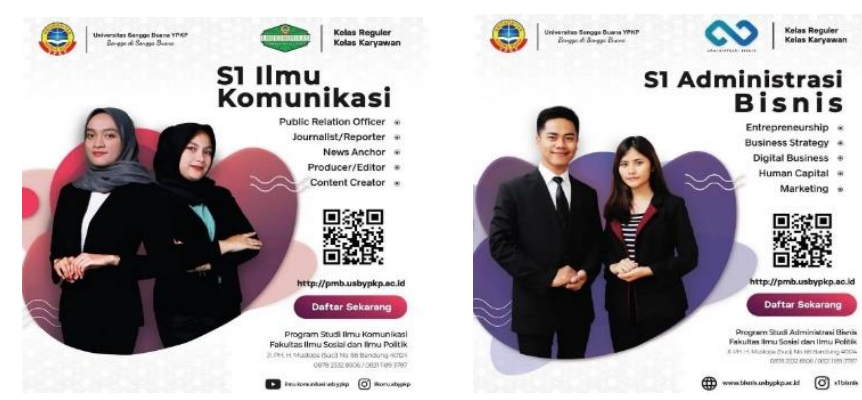

Gambar 3.1

Konten Promosi

Sumber : instagram

2. Faktor yang menjadi pendukung dan penghambat strategi pemasaran online untuk meningkatkan volume jumlah mahasiswa di masa pandemi ini.

Faktor-Faktor Strategi Pemasaran Menurut Tjiptono (2010:8), kemampuan strategi pemasaran suatu perusahaan untuk menanggapi setiap perubahan kondisi pasar dan faktor biaya tergantung pada analisis terhadap faktor-faktor sebagai berikut:

a. Faktor Lingkungan

Analisis terhadap faktor lingkungan seperti pertumbuhan populasi dan peraturan pemerintah sangat penting untuk mengetahui pengaruh yang ditimbulkannya pada bisnis perusahaan. Selain itu faktor-faktor seperti perkembangan teknologi, tingkat inflasi dan gaya hidup juga tidak boleh diabaikan. Hal-hal tersebut merupakan faktor lingkungan yang harus dipertimbangkan sesuai dengan produk dan pasar perusahaan.

b. Faktor Pasar

Setiap perusahaan perlu selalu memperhatikan dan mempertimbangkan faktor-faktor seperti ukuran pasar, tingkat pertumbuhan, tahap perkembangan, trend dalam sistem distribusi, pola perilaku pembeli, permintaan musiman, segmen pasar yang ada saat ini atau yang dapat dikembangkan lagi, dan peluangpeluang yang belum terpenuhi.

c. Persaingan

Dalam kaitannya dengan persaingan, setiap perusahaan perlu memahami siapa pesaingnya, bagaimana posisi produk/pasar pesaing tersebut, apa strategi mereka, kekuatan dan kelemahan pesaing, struktur biaya pesaing, dan kapasitas produksi para pesaing.

d. Analisis Kemampuan Internal

Setiap perusahaan perlu menilai kekuatan dan kelemahannya dibandingkan para pesaingnya. 38 | JURNAL DIMMENSI | Vol.2 | No.1 | 2022 
Penilaian tersebut dapat didasarkan pada faktorfaktor seperti teknologi, sumber daya finansial, kekuatan pemasaran.

e. Perilaku Konsumen

Perilaku konsumen perlu dipantau dan dianalisis karena hal ini sangat bermanfaat bagi pengembangan produk, desain produk, penetapan harga, pemilihan saluran distribusi, dan penentuan strategi promosi. Analisis perilaku konsumen dapat dilakukan dengan penelitian (riset pasar), baik melalui observasi maupun metode survei.

f. Analisis Ekonomi

Dalam analisis ekonomi perusahaan dapat memperkirakan pengaruh setiap peluang pemasaran terhadap kemungkinan mendapatkan laba. Analisis ekonomi terdiri atas analisis terhadap komitmen yang diperlukan, analisis BEP (break even point), penilaian risiko/laba, dan analisis faktor ekonomi pesaing.

Bila dikaitkan teori tersebut dengan hasil penelitian, maka faktor pendukung dan penghambat strategi pemasaran online Fisip Sangga Buana sangat dipengaruhi oleh faktor lingkungan dikarenakan masa pandemi penghambat dalam strategi pemasaran yaitu keterbatasan dalam menyampaikan pesan yang ingin disampaikan seringkali tidak tersampaikan dengan baik, lalu masih ada dosen dari pihak internal belum turut membantu promosi online, adapun faktor pendukungnya yaitu dari faktor lingkungan internal memiliki sumber daya manusia yang cukup baik dan memiliki kemampuan yang baik di bidangnya. Selain itu juga karena masa pandemi penggunaan gadget yang cenderung sangat umum digunakan masyarakat juga sangat membantu dalam strategi promosi online Fisip Sangga Buana.

3. Jenis-jenis promosi pemasaran yang diterapkan oleh Fakultas Fisip Universitas Sangga Buana dalam menarik minat mahasiswa di masa pandemi.

Menurut Kompasiana, Media Sosial merupakan bagian dari internet yang memiliki fungsi salah satunya sebagai media yang digunakan untuk mempromosikan produk atau jasa yang digunakan oleh pelaku usaha. Media sosial digunakan sebagai alat promosi karena memiliki respon secara langsung dengan penggunanya.Selain itu menurut Sekawan, Media Webinar merupakan jenis atau alat media promosi baru yang muncul pasca pandemi.

Bila di kaitkan teori tersebut dengan hasil penelitian maka, untuk Fisip sendiri selain memasang Iklan pada sosial media seperti Instagram ads Tim promosi online Fisip juga memuat konten yang menarik dan menguploadnya di media sosial untuk memikat para calon mahasiswa selain itu webinar juga merupak jenis promosi lain yang digunakan event webinar ini sangat berguna untuk memperkenalkan Fisip Sangga buana melalui event-event yang diadakan dengan lembaga-lembaga eksternal dengan menyelipkan konten promosi yang menarik.
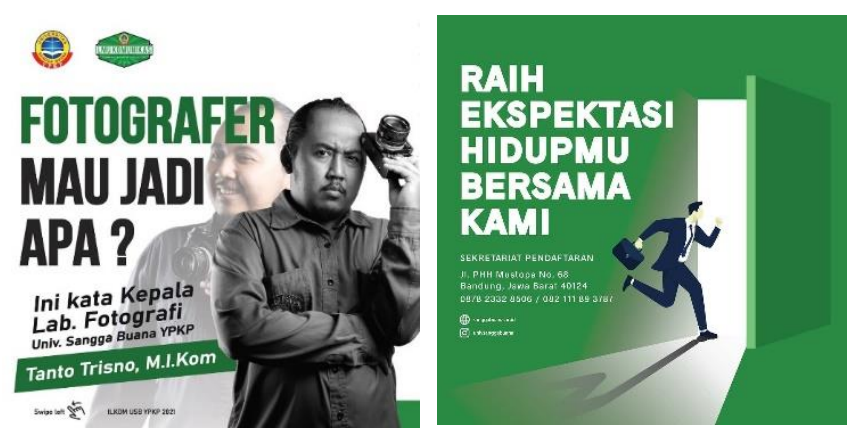

\author{
Gambar 3.2 \\ Konten Promosi \\ Sumber : Instagram
}

4. Cara Fakultas Fisip membangun brand awareness di internet untuk menggaet perhatian calon mahasiswa.

Menurut (Cahyani, 2016) Brand Awareness adalah kemampuan seorang konsumen sehingga dapat mengenali atau dapat mengingat kembali merk sehingga konsumen dapat mengaitkannya dengan satu kategori produk tertentu. Oleh karena hal tersebut, maka seorang konsumen dapat memiliki kesadaran merk terhadap sebuah merk dengan otomatis sehingga mampu menggambarkan elemen suatu merk tanpa bantuan.

Bila teori tersebut dikaitkan dengan hasil penelitian, Fisip sendiri melakukannya dengan memperbanyak event-event external, bekerja sama dalam lembaga media-media eksternal agar lebih mudah dan lebih dikenal oleh banyak orang. Selain itu, dibuatnya pods seperti sapaan "ilkomers" dan "keren adbis" yang akan menjadi sapaan khas untuk Fisip sendiri. Cara tersebut juga merupakan bagian dari mempertahankan serta meningkatkan akreditasi, dengan melihat persaingan Universitas di Bandung yang sangat ketat.

5. Cara pelayanan Fakultas Fisip terhadap calon mahasiswa baru yang telah mendaftar secara online

Pendaftaran adalah pencatatan hal atau identitas seperti nama, alamat dan sebagainya dalam suatu lembaga pendidikan, pendaftaran merupakan suatu hal yang sangat penting.

Pendaftaran selama masa pandemi dilakukan dengan dua acara, yaitu secara online dan offline. Secara online, calon maba atau mahasiswa baru akan diberitahu tahap demi tahap secara detail. Jika masih ada yang kurang mengerti, bisa meminta bantuan kepada pihak IT dengan konsultasi di Whatsapp. Bagi calon mahasiswa baru yang mendaftar secara offline, bias langsung ke Universitas Sangga Buana di ruang pendaftaran yang terletak di bagian depan, atau akan di arahkan oleh Satpam.

Setelah calon mahasiswa masuk ke Fakultas Fisip, berikutnya akan diberikan pelayanan secara penuh dan dilakukan pembinaan oleh dosen wali. Mahasiswa Baru akan disambut melalui acara yang akan dibuat secara menarik dengan tema mengikuti perkembangan anak millenials, juga diciptakan nya citra para dosen yang tidak kaku dan menghibur dalam acara penyambutan tersebut.

39 | JURNAL DIMMENSI | Vol.2 | No.1 | 2022 
Kemudian adanya link yang akan berpusat dan mengumpulkan para calon mahasiswa.
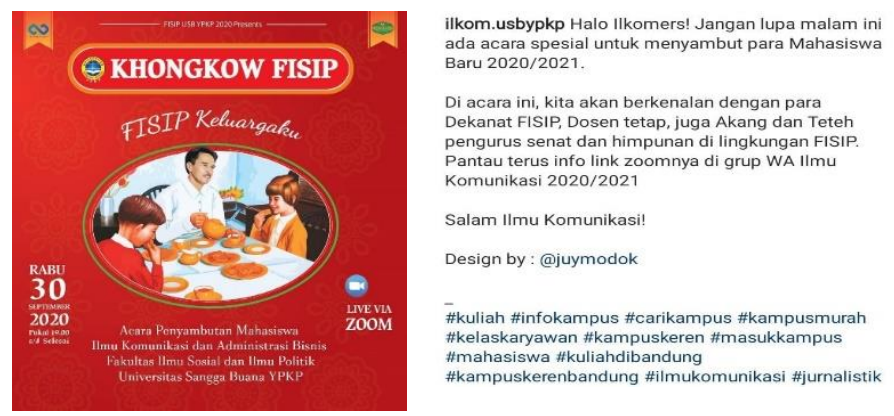

Gambar 3.3

Konten Promosi

Sumber : Instagram

\section{KESIMPULAN}

Perencanaan strategi pemasaran online untuk meningkatkan volume jumlah mahasiswa di masa pandemi berjalan dengan baik dilakukan pada akun Instagram kampus, dan lebih lengkapnya pada akun Instagram Fisip. Kegiatan Promosi Online melakukan perencanaan dan menentukan tema konten yang akan di buat untuk pemasaran online, mempublish semua konten yang dibuat dan mendesagin koten.

Faktor yang menjadi pendukung dan penghambat strategi pemasaran online dalam meningkatkan volume jumlah

\section{DAFTAR PUSTAKA}

\section{Buku :}

Dedi, dan Solatun, (2007). Oxford: Oxford University Press Mulyana.

Endraswara, Suwardi .(2012). Metodologi Penelitian Kebudayaan. Yogyakarta: Gadjah Mada University Press.

Horby, A S.,(1989). Oxford Advanced Learner's Dictionary, Fourth Edition.

Philip Kotler,dan Gary amstrong.(2008). Prinsip-Prinsip Pemasaran. Jakarta: Erlangga.

Rangkuti,Freddy.(1997). Riset Pemasaran. Jakarta : Gramedia pustaka utama.

Yin, Robert K, Case Study Research.(1994). Thousand Oaks, London, New Delhi: SAGE Publications, 1994.

\section{Jurnal :}

Sutrasmawati,SE. Pengaruh Brand Awareness dan Brand Image Terhadap Keputusan Pembeli. Journal.unnes.ac.id. mahasiswa di masa pandemi yaitu adanya faktor pendukung SDM, anggaran (khusus) dan tim yang kompak. Sedangkan yang menjadi faktor penghambatnya adalah belum semua dosen, terutama dosen tetap yang mau bersedia mempromosikan konten yang telah dibuat oleh Tim Promosi dan terkadang pemasaran secara online kurang efektif karena masih di butuhkannya pemasaran secara langsung atau offline agar pesan yang disampaikan tersampaikan dengan jauh lebih baik.

Jenis-jenis promosi pemasaran yang diterapkan oleh tim promosi online fisip dalam menarik minat mahasiswa di masa pandemic yaitu mengadakan webinar pelatihan dengan adanya hadiah menarik seperti beasiswa USB, tabungan emas, tab, dll, lalu membuat konten secara online di Instagram Dan media sosial lain dan memasang iklan di berbagai platform media sosial.

Cara Tim Promosi Online Fisip membangun brand awareness di internet untuk menggaet perhatian calon mahasiswa dengan memperbanyak event-event external, membangun kerjasama di media-media eksternal agar lebih dikenal oleh lebih banyak orang, meningkatkan serta menjaga kualitas mahasiswa dan dosen, lalu mempertahankan serta meningkatkan akreditasi. Cara pelayanan Tim Promosi Online Fisip terhadap calon mahasiswa baru yang telah mendaftar secara online yaitu pendaftaran selama masa pandemi secara online dan offline. Mahasiswa masuk ke Fakultas Fisip akan diberikan pelayanan secara lengkap dan dilakukan pembinaan oleh dosen wali.

\section{Situs Internet :}

Barreto,O, (2018). Tinjauan Pustaka dan dasar Teori. Diakses dari :

https://eprints.akakom.ac.id/8038/3/3_135610131_BA B\%20II.pdf [Accessed 6 September 2021]

Ramanta,Z. (2017). Bab II Tinjauan . Pustaka.Palembang:Polsri.ac.id. Diakses dari : http://eprints.polsri.ac.id/5018/3/BAB\%20II.pdf [Accessed 6 September 2021]

Safira, Putry Nadia. (2018). Pemanfaatan Media Sosial sebagai Media Promosi Baru dalam Usaha Kuliner. Diakses dari: https://www.kompasiana.com/putrynadiasafira3957/5b 4df89f6ddcae2eb669c112/media-sosial-sebagai-mediapromosi-baru-dalam-usahakuliner\#: :text=Media\%20sosial\%20merupakan\%20ba gian $\% 20$ dari,respon $\% 20$ secara $\% 20$ langsung $\% 20$ denga n\%20penggunanya [Accessed 6 September 2021] 